\title{
DISCIPLINA E COALIZÕES PARTIDÁRIAS \\ NA ASSEMBLÉIA LEGISLATIVA \\ DE SANTA CATARINA (1999-2006)
}

\section{Yan de Souza Carreirão \\ Eduardo Perondi}

\section{Introdução}

A literatura brasileira já conta com uma produção significativa sobre temas da disciplina partidária e das coalizões no Legislativo, no âmbito da Câmara Federal. No que concerne aos estados, no entanto, a produção é bem mais modesta. Este trabalho visa contribuir para o debate em torno desses temas no âmbito subnacional, analisando o grau de disciplina partidária e os padrões ideológicos das coalizões realizadas em plenário, nas votações nominais ocorridas na Assembléia Legislativa de Santa Catarina entre 1999 e 2006. Quanto à disciplina, as questões centrais respondidas pela análise são: a) As taxas de disciplina (ou coesão) e de previsibilidade das votações são de magnitudes semelhantes às encontradas nos estudos sobre a Câma-

Artigo recebido em novembro/2008

Aprovado em setembro/2009 ra dos Deputados?; b) Há variações significativas entre os diferentes partidos (do governo e da oposição; da esquerda, do centro e da direita)?; c) Qual o peso das abstenções e ausências dos deputados sobre a previsibilidade dos resultados das votações? No que se refere às coalizões, o estudo verifica se elas seguem os mesmos padrões ideológicos nas duas legislaturas analisadas, ou se o grau de consistência ideológica das coalizões depende do posicionamento dos partidos em face da polaridade governo-oposição, já que os alinhamentos entre a dimensão ideológica e a dimensão que divide governo e oposição são diferentes nas duas legislaturas analisadas.

O trabalho inicia resenhando o debate sobre o processo legislativo em âmbito nacional e em Santa Catarina, passando a apresentar os dados relativos à disciplina (ou coesão) partidária na Assembléia Legislativa do Estado de Santa Catarina - Alesc. 
Nas seções seguintes são apresentados um breve estudo sobre a previsibilidade das votações no plenário e uma análise dos padrões de coalizões realizadas em plenário nas duas legislaturas. Ao final são apresentadas as principais conclusões.

\section{Revisão da literatura}

Até meados da década de 1990 o diagnóstico predominante na literatura brasileira afirmava que devido a conformações institucionais - especialmente a forma de governo presidencialista, a legislação partidária e o sistema eleitoral proporcional com lista aberta, nas eleições legislativas - a atuação do parlamentar nos legislativos seria essencialmente individual, não disciplinada partidariamente, trazendo problemas de governabilidade (no sentido estrito do Executivo conseguir apoio parlamentar para implementar seu programa de governo). A partir de então, estudos como de Figueiredo e Limongi (1995, 1999), em especial, passam a se contrapor às conclusões deste diagnóstico. Segundo os autores, embora haja realmente incentivos para uma ação individual, advindos da legislação eleitoral e partidária, há, por outro lado, mecanismos institucionais, tanto na Constituição como nos Regimentos Internos das casas legislativas, que atuam no sentido de dar ao Executivo ampla capacidade de implementar sua agenda. ${ }^{1}$ Em razão desses poderes, dos recursos de patronagem à disposição do Executivo e das regras que favorecem as lideranças partidárias (em especial seu poder de agenda), o Executivo, com o auxílio dos líderes dos partidos que formam sua bancada, comanda o processo Legislativo: a agenda do Executivo tramita mais rápido e tem índices mais elevados de aprovação do que a agenda proposta pelos parlamentares. O Legislativo, portanto, não tem se constituído em obstáculo à ação do Executivo.

Quanto à disciplina partidária e às coalizões em plenário, Figueiredo e Limongi, analisando o período de 1989 a 1994, concluíram que

[...] os partidos apresentaram considerável coesão média no período como um todo, muito acima do aceitável, visto que os encaminhamen- tos dos líderes permitem antever o resultado da votação. ${ }^{2}$ Além disso, o quadro partidário que emerge da análise revela um padrão de coalizões partidárias que é coerente com a disposição dos partidos num continuum ideológico. Podemos falar tranqüilamente em partidos de direita, centro e de esquerda (1999, p. 75).

Este diagnóstico, que subverte a percepção dominante anteriormente, é por sua vez questionado ou matizado por outros autores. Defendendo a percepção anterior, Mainwaring, com base em dados relativos às votações da Constituinte brasileira de 1987-1988, conclui que "o PT e os pequenos partidos de esquerda demonstram uma disciplina quase perfeita, mas as organizações catch-all são menos disciplinadas no Brasil do que na maioria das democracias ocidentais" (2001, p. 182). ${ }^{3}$

Ames (2003) também questiona metodologicamente os achados de Figueiredo e Limongi, afirmando que esses autores, quando consideram apenas as propostas que vão à votação, acabam por superdimensionar a influência do Executivo no processo decisório. Ao lançar propostas como balões de ensaio, percebendo a possibilidade de resistência à sua aprovação, o Executivo nem chegaria a encaminhá-las ao Congresso. Além disso, o Executivo teria que negociar demasiado, de forma que muitas de suas propostas só seriam aprovadas após uma série de modificações, muitas vezes desfigurandoas fortemente. Segundo Ames, os parlamentares no Brasil em geral têm se comportado de forma a dificultar a governabilidade. Em texto mais recente, Limongi (2006) discute as críticas de Ames e outros autores.

Por sua vez, Santos, comparando o período entre 1986 e 2004 com o período de 1946 a 1964, afirma:

[...] por um lado, os índices de disciplina calculados em relação às votações nominais podem representar a última fase de um processo intenso de barganha, como aponta Ames (2001), e este fato não é irrelevante, pois os índices podem não revelar os custos de transação envolvidos. No entanto, de outro lado, é fundamental considerar que os índices do período 
pós-Constituição de 1988 são consistentemente mais elevados do que no período democrático anterior (que também era um regime presidencialista, federal e com representação proporcional de lista aberta). Ou seja, o argumento de Ames não ajuda a explicitar a variação entre os períodos. A levar em conta, principalmente, os trabalhos de Figueiredo e Limongi (1999) e Santos (2003) a explicação residiria na centralização do processo decisório na presidência e nas lideranças partidárias (Santos, 2006a, p. 235).

Jairo Nicolau, por seu turno, analisando o período do primeiro mandato do presidente Fernando Henrique Cardoso, verifica variações significativas entre as taxas de disciplina dos diferentes partidos, concluindo que

[...] mais do que um atributo sistêmico (alta ou baixa disciplina de todos os partidos), o que chama a atenção no caso brasileiro é a variação [...] o PCdoB e o PT têm taxas de disciplina semelhantes aos mais disciplinados partidos europeus; o PFL, o PSDB, o PDT, o PSB e o PTB apresentam índices próximos aos dos partidos americanos e aos dos partidos europeus menos disciplinados; o PMDB, o PPB e o PL têm taxas de disciplina abaixo das conhecidas na Europa e nos EUA (Nicolau, 2000, p. 717).

Já Amorim Neto (2000 e 2006) indica que, dependendo das estratégias dos presidentes na formação de governos, o comportamento das bancadas varia, o que pode afetar a disciplina partidária de um governo a outro. Análises recentes (Santos e Vilarouca, 2004; Santos, 2006a; Figueiredo e Limongi, 2007), que incluem dados relativos ao primeiro mandato do governo Lula (em todo ou em parte), mostram que a disciplina de alguns partidos sofreu redução significativa em relação ao segundo mandato de FHC. Figueiredo e Limongi (2007) mostram que houve uma queda das taxas de disciplina tanto nos partidos de oposição (PSDB, de 95\% para $73 \%$, e PFL, de $93 \%$ para 71\%), como no PT (de 99\% para 92\%). Analisando estes dados, Melo afirma que
No caso do PT é possível dizer que a chegada ao governo e a conseqüente adoção de uma agenda política moderada gerou tensões entre a bancada e nas relações desta com o governo, a militância e o eleitorado mais próximo. Como resultado, o partido viu sua coesão diminuída e seus líderes tiveram que em algumas ocasiões lançar mão dos instrumentos disciplinares disponíveis para manter a bancada alinhada no apoio ao governo. Já os casos do PFL e PSDB revelam a dificuldade dos líderes em manter o nível de disciplina dos deputados uma vez destituídos dos importantes recursos disponíveis aos partidos governistas (Melo, 2007, p. 287).

De acordo com Santos e Vilarouca (2004), a indisciplina vem à tona principalmente com a ausência nas votações no plenário e não por causa da declaração de voto contrário dos membros da bancada. ${ }^{4}$ Os autores utilizam dois indicadores de disciplina: primeiramente só com os parlamentares presentes no momento da votação e, depois, computando a ausência. Esta seria a principal forma de alguns deputados não seguirem a indicação do seu partido. Mostram, portanto, que a indisciplina é bem maior quando se computa as ausências. Tipo semelhante de análise será realizado aqui, para verificar o efeito das ausências e das abstenções sobre a coesão partidária.

Quanto às coalizões partidárias no plenário (nas votações nominais), os estudos mais recentes indicados acima mostram que ao longo do primeiro mandato do governo Lula houve uma mudança em relação aos padrões encontrados no período de 1988 a 2002. Segundo Santos e Vilarouca (2004), o governo Lula trouxe impactos significativos sobre o desempenho dos partidos e no próprio modo de operação do presidencialismo de coalizão. A hipótese de coerência ideológica das coalizões não se manteve nesse governo por conta de suas alianças com partidos de direita. O tom do posicionamento dos partidos deixa de ter um sentido ideológico para assumir um aspecto de simples disputa centrada na dicotomia governo/oposição. É evidente, em suma, o aumento significativo da inconsistência ideológica quando se compara os dois primeiros anos do governo Lula com os cerca de quinze anos 
anteriores. $\mathrm{O}$ que parece ter mantido a coerência ideológica das coalizões em plenário até o segundo mandato do presidente Fernando Henrique Cardoso é a coincidência entre a dimensão ideológica e a dimensão que divide governo e oposição: desde o governo Sarney até FHC, havia governos de centro-direita, com a esquerda, nucleada pelo PT, na oposição. Quando o PT chega ao governo, fazendo composições ideologicamente inconsistentes (e tendo, na oposição, uma base também inconsistente ideologicamente), mantém-se em grande parte a divisão, nas votações em plenário, entre partidos governistas, de um lado, e partidos de oposição, de outro. Esta é a dimensão que parece ser dominante na formação das coalizões no momento das votações nominais no plenário da Câmara Federal. As coalizões só tendem a ser ideologicamente consistentes se a composição dos governos (formação de ministérios) for também ideologicamente consistente.

Concluindo: a partir dos estudos iniciais de Figueiredo e Limongi sobre a Câmara Federal, o diagnóstico inicialmente predominante na literatura brasileira - de um sistema político ingovernável, devido à fragmentação e à indisciplina partidária - é invertido. Como vimos, as primeiras análises nesse sentido apontavam para taxas elevadas de disciplina partidária e um grau significativo de consistência ideológica das coalizões em plenário. Estudos posteriores, porém, têm contribuído para relativizar tais conclusões, seja questionando aspectos metodológicos, seja mostrando variações nas taxas de disciplina entre diferentes partidos e governos variações não explicáveis pelas variáveis institucionais enfatizadas por Figueiredo e Limongi para explicar as altas taxas de disciplina. O debate em torno dessas questões tem desenvolvido uma agenda de pesquisa das mais profícuas, ${ }^{5}$ ampliando muito a reflexão teórica e o conhecimento empírico a respeito do sistema político brasileiro. É a partir dessas reflexões que o presente trabalho pretende analisar dados sobre disciplina e coalizões partidárias em Santa Catarina.

No que diz respeito aos estados brasileiros, a bibliografia sobre o processo legislativo é mais escassa. Dessa forma, os estudos coordenados por Abrucio (1998), Andrade (1998) e Santos (2001), entre outros, constituem-se em importante contribuição para uma reflexão sobre os sistemas políticos estaduais, particularmente no que se refere às relações entre Executivo e Legislativo. No que tange especificamente à disciplina partidária e às coalizões em plenário, porém, a análise em âmbito estadual é inexistente.

Quanto ao estado de Santa Catarina, embora não se detenham diretamente nos temas aqui analisados, os trabalhos de Montenegro (2006) e Tomio (2006) merecem menção, pois apontam importantes tendências no processo de produção legislativa na Alesc e nas relações entre Executivo e Legislativo. Montenegro, analisando a produção de leis na Assembléia Legislativa catarinense, entre 1990 e 2000, conclui que neste processo predominam as "leis do subtipo Declaração de Utilidade Pública. Esta constatação revela a prori um vínculo entre deputados e diferentes organizações da sociedade civil". Além disso, constata uma mudança no comportamento dos deputados, à medida que conseguem renovar seus mandatos:

[...] até o segundo mandato os deputados procuram produzir leis clientelistas que lhes proporcionem uma estabilidade eleitoral. A partir do segundo mandato o deputado reconhece uma base eleitoral estável que lhe proporciona um novo patamar na carreira. Entre as opções neste novo patamar o deputado escolhe entre continuar na carreira estadual, procurando ocupar cargos na estrutura da Alesc, principalmente o de presidente da casa, ou garantir uma indicação como juiz do Tribunal de Contas do Estado; neste caso, sua propensão ao clientelismo é maior; ou optar por uma ascensão na carreira, na busca de um cargo federal, que para tanto necessitará de uma ampliação de sua base eleitoral, possível através de uma produção de leis menos clientelistas (Montenegro, 2006, p. 168).

Tomio, analisando o processo legislativo na Assembléia Legislativa catarinense entre 1995 e 2005 mostra a grande dependência de proposições legislativas originadas do Executivo, mesmo em governos fracos, devido às prerrogativas legislativas exclusivas deste ator; a numerosa produção legislativa originada entre os parlamentares estaduais, o que 
indica a existência de uma agenda decisória autônoma no Legislativo; a capacidade efetiva do Legislativo em derrubar os vetos do Executivo, mesmo diante de coalizões majoritárias, restringindo a eficácia das hipóteses de subordinação do Legislativo estadual; o declínio, no decorrer da legislatura, da aprovação de proposições originadas no Executivo; a determinação que os mecanismos de democracia participativa (plebiscitos) e a iniciativa popular têm na autonomia do Legislativo ante o Executivo; a pouca relevância do poder de decreto (Medidas Provisórias) na determinação do processo decisório catarinense. O autor conclui que há, no âmbito da produção legislativa,

[...] pelo menos quatro processos distintos: 1) um processo legislativo que regulamenta [...] o funcionamento da máquina administrativa do governo [...], em que o governo é proativo e possui poderosas prerrogativas legislativas [...]; 2) um processo legislativo compartilhado pelos dois poderes, principalmente direcionado a definir as normas e diretrizes das políticas públicas estaduais [...]; 3) um processo extenso de produção de leis de baixo efeito distributivo e leis honoríficas, onde os legisladores jogam autonomamente [...]; 4) um processo decisório que incorpora mecanismos de democracia direta (plebiscito...), temporariamente suspenso, dado que restringiu-se à criação de municípios [...] (Tomio, 2006, p. 130).

\section{Análise dos dados: contexto histórico e aspectos metodológicos}

Antes de passarmos a analisar os dados relativos à disciplina (ou coesão) partidária e aos padrões de coalizão em plenário na Alesc, no período entre 1999 e 2006, é importante mencionar alguns dos principais aspectos metodológicos envolvidos na coleta e na análise dos dados e situar alguns elementos do contexto político relativo às eleições e às legislaturas em estudo.

A pesquisa cobriu apenas as votações nominais consideradas não-consensuais. Adotamos o critério sugerido por Figueiredo e Limongi (1999) e seguido também por Santos (2006), de definir como nãoconsensual a votação em que a proposta mais votada obteve menos de $90 \%$ do apoio dos presentes. ${ }^{6}$ Resulta daí um conjunto de 276 votações nominais, que incluem todas as realizadas na Alesc no período em estudo consideradas não-consensuais (125 na $14^{\mathrm{a}}$ Legislatura e 151 na $15^{\mathrm{a}}$ ). Outras 362 votações realizadas durante o período foram deixadas de fora da análise por serem consideradas consensuais com base no critério adotado.

Quanto ao contexto político, vale a pena indicar que Santa Catarina apresentou até recentemente um predomínio conservador no âmbito políticopartidário, comparativamente à correlação de forças vigente em plano nacional. Desde o final da República Velha até o golpe de 1964, o estado foi dominado politicamente por dois grupos políticos centrados em duas famílias: os Ramos e os Konder Bornhausen, que dominaram, respectivamente, o PSD e a UDN entre 1946 e 1964. Após o golpe de 1964, as "oligarquias" rivais rapidamente se acertaram dentro da Arena (Aliança Renovadora Nacional), partido de apoio ao regime autoritário. Ao longo do período em que vigorou o sistema bipartidário (1965/1979), os Ramos declinaram sua força política, enquanto os Konder Bornhausen conseguiram articular as principais forças políticas do estado, tendo dois de seus membros (Antônio Carlos Konder Reis e Jorge Konder Bornhausen) exercido o cargo de governador. Ao final daquele período, a Arena ainda tinha o predomínio eleitoral, embora o MDB tivesse crescido e já representasse uma ameaça.

Sob o atual sistema partidário, o PP (PPB/PDS) capitaneado pelo casal Esperidião e Ângela Amin e o PMDB têm sido os dois maiores partidos ao longo de todo o período. O PFL vinha sendo, até as eleições de 2002, o terceiro maior partido do estado. Mas, a partir daí, o PT passou a ter um desempenho próximo ao PFL. O PSDB estadual é, comparativamente ao plano nacional, um partido ainda pequeno, mas obteve resultados muito positivos nas eleições municipais de 2004 e 2008. Especialmente a partir das eleições de 2002 houve uma ampliação do pluralismo partidário e ideológico efetivo no âmbito do processo político catarinense. Se até 1982 podemos falar num sistema político 
oligárquico, de lá para cá pode-se dizer que ocorreu uma transição para um sistema efetivamente poliárquico (Dahl, 1999).

Feito este retrospecto, é necessário indicar quais partidos formavam o bloco de apoio ao governo e quais estavam na oposição, além de situar o número de deputados de cada partido nas duas legislaturas. O Quadro 1 aponta o posicionamento dos partidos em relação ao Executivo (na maioria do tempo relativo a cada legislatura), porém devem ser consideradas as observações formuladas a seguir, de forma a matizar tais posicionamentos. ${ }^{7}$

Em relação ao tamanho de cada bancada partidária, houve algumas variações ao longo de cada legislatura devido às migrações de deputados de um partido a outro e também ao fato de que, quando um deputado se afasta do cargo, às vezes o suplente é de outro partido, coligado (no momento da eleição) ao do deputado titular que está se afastando. $^{8}$

\section{Quadro 1}

\section{Posição de Cada Partido em Relação ao poder Executivo}

\begin{tabular}{llll}
\hline Legislatura & Governador (e partido) & \multicolumn{1}{c}{ Governo } & Oposição \\
\hline $14^{\mathrm{a}}(1999-2002)$ & Esperidião Amin (PPB) & PP, PFL, PTB, PL, PSDB & PMDB, PT, PDT, PPS \\
$15^{\mathrm{a}}(2003-2006)$ & $\begin{array}{l}\text { Luis Henrique da Silveira } \\
\text { (PMDB) }\end{array}$ & $\begin{array}{l}\text { PMDB, PSDB, PTB, PL, } \\
\text { PPS, PDT, PSB, PFL* }\end{array}$ & PP, PSOL, PT* \\
\hline
\end{tabular}

* Ver observações sobre posicionamentos de PFL e PT na 15ª Legislatura.

Fonte: Núcleo de Estudos em Comportamento e Instituições Políticas - Necip/UFSC (a partir de entrevistas com líderes e assessores do PPB e do PMDB).

A formação da coalizão de governo da $14^{\mathrm{a}}$ Legislatura (1999-2003) obedeceu à composição da coligação que venceu as eleições de 1998, apoiando Esperidião Amin. Os partidos que compunham a coligação Mais Santa Catarina (PPB, PFL, PTB, PL e PSDB) e que conseguiram inicialmente 23 cadeiras na Assembléia Legislativa continuaram juntos durante o decorrer de toda a legislatura. O governo possuía nesse período a maioria das cadeiras, ainda que por uma pequena margem de diferença. A formação da coalizão de governo parece ter obedecido também a (ou coincidido com) um padrão ideológico, haja vista que entre os partidos que a compunham todos eram de direita, segundo a classificação que adotamos, salvo o PSDB, classificado como um partido de centro. $\mathrm{Na}$ oposição ficaram todos os partidos de esquerda com representação na Casa (PT, PDT e PPS) e o PMDB (de centro). A variação do número de deputados da base do governo foi pequena. Nenhum outro partido migrou para a bancada governista no decorrer da legislatura. Tampouco os partidos situacionistas se deslocaram para a oposição. ${ }^{9}$ Quanto às migrações de deputados de um partido para outro, a variação foi pequena, especialmente se considerado o saldo das migrações (de saída e entrada no bloco governista). ${ }^{10}$

$\mathrm{Na}$ coalizão do governo Luiz Henrique da Silveira (LHS), do PMDB, na 15 Legislatura (20032006), participaram partidos de diferentes matizes ideológicos (esquerda, centro e direita). A oposição formou-se por partidos à direita e à esquerda, num padrão bastante diferente da $14^{\mathrm{a}}$ Legislatura. Luiz Henrique, embora tenha sido apoiado no $1^{\circ}$ turno da eleição de 2002 por uma coligação de apenas dois partidos (PMDB e PSDB), consegue o apoio já no $2^{\circ}$ turno de muitos outros partidos. Cabe destacar as modificações de posicionamento de PT e PFL ao longo da legislatura. O PT, que havia apoiado LHS no $2^{\circ}$ turno, inicia a legislatura com um posicionamento de independência formal, mas, na prática, apoiando boa parte das iniciativas do governo na Alesc, mesmo não participando do secretariado do governador. Ao longo do primeiro ano, porém, o partido passou a mostrar resistência às propostas governistas, e já no segundo ano da legislatura o PT posicionou-se claramente como par- 
tido de oposição. Com o PFL ocorreu o inverso: o Disciplina (ou coesão) partidária partido havia apoiado Amin contra Luiz Henrique na eleição de 2002 e começou a legislatura na oposição. No entanto, a partir de uma estratégia bem-sucedida de aproximação entre o governador e alguns parlamentares, os deputados pefelistas passaram gradativamente a apoiar as decisões do Executivo, e o partido terminou o mandato não apenas como integrante da base de Luiz Henrique, mas também como componente da coligação que viria a reelegê-lo em $2006 .{ }^{11}$

$\mathrm{Na}$ análise da disciplina partidária na Câmara Federal, um dos indicadores relevantes é a porcentagem de deputados que votam na forma indicada pelo líder de seu partido. Como se pode observar na Tabela 1, o número de vezes em que os líderes declaram publicamente seu voto, indicando a seus liderados como votar, é muito pequeno no caso das votações nominais na Alesc.

Tabela 1

Disciplina Partidária (percentual de votos* em acordo com a indicação do líder), por Partido e Posicionamento Ideológico ${ }^{12}$

\begin{tabular}{lccccc}
\hline Legislatura & \multicolumn{2}{c}{ Direita } & \multicolumn{2}{c}{ Centro } & Esquerda \\
\cline { 2 - 5 } & PP & PFL & PMDB & PSDB & PT \\
\hline $14^{\mathrm{a}}(1999-2002)$ & 92,6 & 93,1 & 92,8 & 91,7 & 98,1 \\
$15^{\mathrm{a}}(2003-2006)$ & 80,8 & 86,5 & 98,8 & 97,5 & 93,6 \\
Total & 86,5 & 87,8 & 94,7 & 95,0 & 95,9 \\
$(\mathrm{~N})$ & $(62)$ & $(35)$ & $(38)$ & $(14)$ & $(82)$ \\
\hline
\end{tabular}

* Média, para o conjunto das votações, dos percentuais de deputados de um partido que votaram de acordo com a indicação de seu líder, em cada votação.

$(\mathrm{N})$ = número (absoluto) de casos em que houve indicação do líder e havia pelo menos dois deputados do partido presentes à votação. Além dos partidos acima, na $14^{\mathrm{a}}$ Legislatura, em 5 votações o PTB se enquadrou nestes critérios; teve $100 \%$ de disciplina nestes casos.

O líder do PT usou este direito em 82 vezes, cerca de $30 \%$ do total das 276 votações nominais aqui analisadas. A seguir, aparece o PP (PPB), em 62 votações (cerca de $22 \%$ do total); quanto aos demais partidos, o uso desta estratégia foi muito secundário.

De toda forma, a disciplina medida desta maneira é bastante alta. A média ponderada dos cinco maiores partidos, no conjunto dos 231 casos em que houve indicação de voto do líder de pelo menos um partido ao longo das duas legislaturas, é de 92\% de disciplina. Especialmente na $14^{a}$ Legislatura, foi bastante alta em todos os partidos (variando de $92 \%$ no PSDB a $98 \%$ no PT). Na $15^{\text {a }}$ Legislatura, há um declínio sensível no PP (PPB) (de cerca de $93 \%$ para $81 \%$ ) e, em menor escala, no PFL (de 93\% para $87 \%$ ) e no PT (de 98\% para 94\%); por outro lado, cresce significativamente a disciplina no
PMDB (que alcança quase 99\%) e no PSDB (quase $98 \%)^{13}$

Os partidos de esquerda (PT) e centro (PMDB e PSDB) têm, no conjunto do período, disciplina muito elevada (entre 95\% e 96\%), enquanto os de direita (PPB/PP e PFL) têm disciplina menor (87\% e $88 \%$, respectivamente). Seguindo o que indicam Figueiredo e Limongi, quando estão numa mesma coalizão (como na 14 $4^{\mathrm{a}}$ Legislatura) os partidos de direita têm maior disciplina do que quando se encontram divididos (como na 15a). Embora com algumas ressalvas, a hipótese de que partidos da base de apoio ao governo tenham maior disciplina sai reforçada da análise destes dados: o PP (PPB) diminuiu sua disciplina quando passou à oposição; $\mathrm{O}$ PMDB, por sua vez, quando passou a ser governo aumentou sua disciplina. Quanto ao PFL, seu posicionamento como "base do governo" era mais claro 
durante o governo Amin (período em que a disciplina foi maior), já que no início do governo Luiz Henrique estava formalmente na oposição. Da mesma forma, o PSDB, embora apoiasse Amin, era aquinhoado naquele governo com parcelas bem menores de poder, sendo considerado um "sócio" menor dentro da coalizão de governo. Isso se altera durante o governo Luiz Henrique, quando o peso do PSDB na coalizão é bem mais significativo, o que parece ter tido impacto no aumento do grau de disciplina dos deputados ao líder partidário na Alesc. Assim, os parlamentares dos partidos que tiveram maior peso na coalizão de governo parecem ter maior incentivo para seguirem as indicações de seus líderes, se comparados aos que foram parte da coalizão, mas tiveram ali um peso menor. Quanto ao PT, nas duas legislaturas o partido permaneceu na oposição. Mas, no início do governo Luiz Henrique havia a expectativa de uma colaboração maior do partido ao governo na Assembléia, ${ }^{14}$ já que o PT havia apoiado Luiz Henrique no $2^{\circ}$ turno, em 2002. Isso acabou não acontecendo, mas o PT, embora tenha mantido sua postura disciplinada e oposicionista, dividiu-se um pouco mais do que durante o governo Amin.
Como no âmbito da Alesc a indicação de voto por parte do líder não ocorre na grande maioria das votações, a análise a seguir utilizará como principal indicador o percentual de coesão partidária, definido como sendo igual à maior porcentagem de deputados do partido que votaram de forma semelhante. Denominaremos indicador da coesão interna da bancada do partido em plenário, uma vez que ele pode não refletir necessariamente disciplina à liderança do partido. ${ }^{15} \mathrm{O}$ indicador de coesão aqui utilizado é inspirado naquele já proposto por Figueiredo e Limongi (1999, p. 82). Não utilizaremos, porém, o índice de Rice por julgá-lo menos intuitivo do que o indicador aqui proposto. ${ }^{16}$

Tomando como universo de análise apenas os deputados presentes no momento de cada votação e que não se abstiveram de votar, os dados da Tabela 2 indicam percentuais relativamente elevados de coesão partidária na Assembléia para todos os partidos relevantes. Mas há variações significativas:, o menor percentual registrado no período de 1999 a 2006 foi obtido pelo PP, com cerca de $87 \%$; o maior percentual médio nesses oito anos foi registrado pelo PT, que votou de maneira coesa em $96 \%$ das 265 votações em que pelo menos dois de seus deputados compareceram e votaram. ${ }^{17}$

Tabela 2

Percentual de Coesão (entre deputados presentes e que não se abstiveram)*, por Partido e Posicionamento Ideológico

\begin{tabular}{lccccccccc}
\hline \multirow{2}{*}{ Legislatura } & \multicolumn{4}{c}{ Direita } & & & Centro & & Esquerda \\
\cline { 2 - 9 } & & PP & PFL & PTB & Total & PMDB & PSDB & Total & PT \\
\hline $14^{\mathrm{a}}(1999-2002)$ & $\%$ & 92,1 & 91,0 & 97,7 & 92,7 & 92,4 & 94,2 & 92,9 & 97,4 \\
& $(\mathrm{~N})$ & $(125)$ & $(124)$ & $(55)$ & $(304)$ & $(123)$ & $(43)$ & $(166)$ & $(121)$ \\
$15^{\mathrm{a}}(2003-2006)$ & $\%$ & 83,0 & 88,4 & 93,9 & 87,2 & 94,3 & 95,4 & 94,8 & 94,3 \\
& $(\mathrm{~N})$ & $(148)$ & $(146)$ & $(66)$ & $(360)$ & $(150)$ & $(149)$ & $(299)$ & $(144)$ \\
\multirow{2}{*}{ Total (1999-2006) } & $\%$ & 87,2 & 89,6 & 95,5 & 89,7 & 93,5 & 95,1 & 94,2 & 95,7 \\
& $(\mathrm{~N})$ & $(273)$ & $(270)$ & $(121)$ & $(664)$ & $(273)$ & $(192)$ & $(465)$ & $(265)$ \\
\hline
\end{tabular}

\footnotetext{
* Média, para o conjunto das votações, dos maiores percentuais de deputados de um partido que votaram de forma semelhante em cada votação, calculados sobre o total de deputados do partido presentes à votação e que não se abstiveram de votar.

Obs.: Os percentuais referentes aos totais de cada "campo ideológico" (direita e centro) representam as médias ponderadas das taxas de coesão dos partidos de cada "campo".
} 
Não há variações significativas no comportamento de cada partido entre as duas legislaturas, com exceção do PP (PPB), cujo percentual de coesão recua de $92 \%$ na $14^{a}$ Legislatura para $83 \%$ na $15^{a}$. Uma explicação que parece ser plausível para explicar essa mudança reside no fato de que esse partido detinha o controle do Executivo estadual na $14^{a}$ Legislatura e na $15^{a}$ ele se deslocou para a oposição. O PP foi o único partido entre aqueles alinhados à direita do espectro ideológico que se colocou claramente no bloco de oposição nesta última legislatura. Em seu estudo sobre a Câmara Federal, Figueiredo e Limongi (1999) constataram que os partidos de direita eram mais coesos caso votassem juntos. Aqui ocorre o mesmo, mas o fato de ter havido uma redução bem maior no percentual de coesão do $\mathrm{PP}(\mathrm{PPB})$ do que nos percentuais de coesão de PFL e PTB, entre uma legislatura e a seguinte, sugere que passar da situação para a oposição tem um peso maior (na redução da coesão), do que passar de uma situação em que os partidos da direita votam juntos para uma em que isso não acontece. Os autores também afirmaram que os partidos de esquerda não passavam pelo mesmo problema, visto que eles seriam de fato mais coesos, independentemente do tipo de aliança e do tipo de conteúdo em pauta. Apesar de o PT ser o único partido de esquerda com número de parlamentares suficiente para ser incluído na nossa análise da coesão interna, e isso limitar o alcance de uma comparação com a Câmara Federal, o que se constata é que também na Alesc o principal partido de esquerda foi o mais coeso no plenário no conjunto das duas legislaturas. Porém, não muito mais do que o PSDB e o PMDB, tendo este último ultrapassado o PT na última legislatura.

À luz deste indicador de coesão, comparativamente ao usado na Tabela 1 (percentual de deputados presentes no plenário que seguiram o voto do líder), são menos intensos os possíveis impactos, devido ao posicionamento das bancadas em relação ao governo. Fazer parte da oposição ou da base do governo (com maior ou menor participação no governo) parece afetar as taxas de coesão, mas de forma menos intensa (com exceção do PP/PPB). Assim, há um pequeno aumento da coesão partidária no PMDB, entre a $14^{\mathrm{a}}$ e a $15^{\mathrm{a}}$ legislaturas quando o partido deixa de ser oposição para se tornar a principal força da coalizão governista no primeiro mandato de Luiz Henrique. Da mesma forma, há um pequeno crescimento da disciplina também no PSDB que, mesmo fazendo parte da coalizão governista nas duas legislaturas, só na última passou a ter peso relevante. Quanto ao PFL e ao PT, sua ambigüidade inicial diante do governo Luiz Henrique parece ter contribuído para uma pequena redução da coesão nesses partidos na $15^{\mathrm{a}}$ Legislatura. No que se refere ao PTB, houve pequeno declínio da coesão entre a $14^{a}$ e a $15^{a}$ legislaturas, embora o partido tenha participado formalmente, mas sem muito peso, da base do governo nas duas.

É importante lembrar que as conclusões alcançadas até aqui consideraram apenas os deputados presentes às votações e que não se abstiveram de votar (ou seja, votaram "sim" ou "não"), ${ }^{18}$ o que torna possível uma comparação com os dados de Figueiredo e Limongi (1999, 2007) que seguiram este procedimento. Autores como, por exemplo, Nicolau (2000), Santos e Vilarouca (2004) e Santos (2006) consideram, porém, que a deserção do deputado no momento da votação em muitos casos pode representar um ato de indisciplina, já que alguns parlamentares, para não se colocarem diretamente contra a determinação da sua liderança, simplesmente se ausentam das votações sem dar uma justificativa. Seguindo essa sugestão, a Tabela 3 apresenta os dados referentes a um novo indicador de coesão, levando em conta, agora, as abstenções e as ausências dos deputados às votações em plenário. ${ }^{19}$

Se compararmos estas taxas com as apresentadas na Tabela 2, vemos que os percentuais de coesão aqui são muito menores. Quando se considerava apenas os parlamentares que estavam presentes às votações e não se abstiveram, os percentuais de coesão dos diferentes partidos, para o conjunto do período, variavam entre $87 \%$ e $96 \%$ (sendo a média ponderada, para o conjunto dos seis maiores partidos, de $92 \%$ ). Quando se levou em conta abstenções e ausências, os percentuais de coesão variaram entre $62 \%$ e $78 \%$ (média ponderada de $70 \%$ ). Houve portanto, no conjunto dos partidos, uma redução de $92 \%$ para $70 \%$, em média, do percentual de coesão, dependendo do indicador utilizado. Comparando, para cada partido, os percentuais de 
Tabela 3

Percentuais de Coesão (considerando deputados que se abstiveram ou se ausentaram das votações)*, por Partido

\begin{tabular}{lccccccc} 
Legislatura & \multicolumn{7}{c}{ Partido } \\
\cline { 2 - 7 } & & PP & PFL & PTB & PMDB & PSDB & PT \\
\hline \multirow{2}{*}{$14^{\mathrm{a}}(1999-2002)$} & $\%$ & 71,2 & 67,1 & 68,9 & 68,8 & 70,6 & 73,8 \\
& $(\mathrm{~N})$ & $(125)$ & $(125)$ & $(103)$ & $(125)$ & $(73)$ & $(125)$ \\
$15^{\mathrm{a}}(2003-2006)$ & $\%$ & 55,3 & 57,8 & 74,3 & 85,8 & 80,1 & 70,3 \\
& $(\mathrm{~N})$ & $(151)$ & $(151)$ & $(103)$ & $(151)$ & $(151)$ & $(151)$ \\
Total (1999-2006) & $\%$ & 62,5 & 62,0 & 71,6 & 78,1 & 77,0 & 71,9 \\
& $(\mathrm{~N})$ & $(276)$ & $(276)$ & $(206)$ & $(276)$ & $(224)$ & $(276)$ \\
\hline
\end{tabular}

* Média, para o conjunto das votações, dos maiores percentuais de deputados de um partido que votaram de forma semelhante em cada votação, calculados sobre o total de deputados filiados ao partido no momento da votação (incluindo os que se abstiveram ou se ausentaram da votação).

Fonte: Necip/UFSC.

coesão medidos a partir dos dois indicadores (Tabelas 2 e 3), percebe-se que as ausências e as abstenções afetam (negativamente) menos as taxas de coesão de PMDB (que diminui de 93,5\% para 78,1\%, uma diferença de cerca de 15\%) e PSDB (diferença de 18\%). Nos demais partidos, incluir ausências e abstenções no cálculo das taxas de coesão leva a uma queda em torno de $25 \%$ (em relação às taxas calculadas apenas sobre os deputados presentes e que não se abstiveram de votar).

Os partidos com menor percentual de coesão (Tabela 3) são o PP (PPB) e o PFL, o que já acontecia utilizando o indicador anterior; depois aparecem o PTB e o P'T e, por fim, o PSDB e o PMDB, com percentuais mais altos de coesão do que os demais, considerando ausências e abstenções.

Quanto à evolução dos percentuais de coesão (levando em conta os dados da Tabela 3), observase que o PP (PPB) teve uma queda acentuada (16\%: de $71 \%$ para $55 \%$ ) ao passar de principal partido da coalizão de apoio ao governo Amin para o maior partido de oposição (durante o primeiro mandato de Luiz Henrique); o PFL apresentou também um declínio significativo (quase 10\%) nesse sentido; e o PT, por sua vez, mostrou uma pequena queda da coesão $(3,5 \%)$; os demais partidos, ao contrário, tiveram crescimento da coesão (PTB: aumento de 5\%; PSDB: 9,5\%; PMDB: 17\%). Considerando, portanto, ausências e abstenções, o fato de o PP e o PMDB estarem na oposição levou a menores percentuais de coesão (em relação aos períodos em que governaram); quanto aos partidos PSDB e PFL, embora estivessem na base dos dois governos, apresentaram mais coesão durante o governo em que tiveram maior peso na coalizão (PFL, no governo Amin, e PSDB, no governo Luiz Henrique). O PT, ficou um pouco mais dividido durante o governo do peemedebista, do que durante o governo Amin. No único ano (2003) em que se aproximou do governo, teve percentual de coesão mais alto, mas nunca maior do que nos anos em que esteve firmemente na oposição.

Em suma, quando utilizamos como indicador de disciplina a porcentagem de deputados que seguem a indicação de voto do líder, observamos um aumento razoavelmente alto de disciplina. Tomando como universo de análise apenas os deputados presentes no momento de cada votação e que não se abstiveram de votar, os percentuais de coesão partidária são também relativamente altos para todos os partidos. Quando consideramos, porém, os deputados que se abstiveram de votar 
ou se ausentaram, as taxas de coesão decrescem significativamente, uma vez que o número de ausências é considerável. Não é possível, contudo, com base nos dados de que dispomos, saber em que medida as ausências expressam uma estratégia de indisciplina velada por parte de deputados.

Embora haja exceções, os partidos de centro e de direita tendem a maiores taxas de disciplina (oucoesão) quando estão na base de apoio ao governo (ou têm maior peso no interior desta base), do que quando estão na oposição (ou têm menor importância na composição do governo). O PT (único partido de esquerda analisado por ser o único com representação significativa na Alesc, no período) manteve-se praticamente todo o tempo como partido de oposição. Mesmo quando se aproximou do governo, suas taxas de coesão não permitem fazer inferências sobre o possível impacto que isso causou em sua disciplina partidária em plenário.

\section{Previsibilidade do Plenário}

$\mathrm{Na}$ esteira da pesquisa de Figueiredo e Limongi (1999, pp. 88ss), verificaremos agora o grau de previsibilidade das votações em plenário. Este estudo basicamente compara os resultados efetivos com os "teoricamente esperados" para cada votação. Pressupomos que todos os deputados de cada partido estivessem presentes no plenário e votassem de forma disciplinada (conforme a indicação de voto do líder), ou de forma coesa (de acordo com a maioria do partido). ${ }^{20}$ Nos casos em que houve empate, no interior de um partido, entre as propostas ("sim" e "não") ou que nenhum deputado compareceu - mas que não houve indicação de obstrução -, consideramos como "posição" desse partido aquela apoiada por outras siglas que compunham a mesma coalizão (de governo ou de oposição). Chegamos, pois, a um "resultado virtual" da votação, que, contrastado com o resultado efetivo, foi bastante previsível. Procedendo dessa maneira em todas as votações, pudemos reconhecer qual a porcentagem das 276 votações nominais era previsível.

De modo análogo à conclusão a que chegaram Figueiredo e Limongi na Câmara Federal, a análise das votações não-consensuais na Assembléia de Santa Catarina mostrou que os resultados das votações podem ser previstos na grande maioria dos casos. Conforme pode ser observado na Tabela 4, as duas legislaturas analisadas apresentaram taxas de previsibilidade muito parecidas entre si $\left(87 \%\right.$ na $14^{\mathrm{a}}$ e $86 \%$ na $15^{\text {a }}$ ) e próximas daquelas encontradas no estudo de Figueiredo e Limongi (89\%).

No que diz respeito à coesão interna dos partidos, ausências e abstenções parecem ter contribuído mais do que dissensões internas explícitas (votos contrários à indicação dos líderes ou ao voto da maioria do partido) para a existência daquele percentual de 13\% de votações não previsíveis, já que quando consideramos apenas os deputados que compareceram às votações temos uma coesão bastante elevada (média, para o período, de $92 \%$ ). Com efeito, seria necessário uma análise mais detalhada para observar o impacto sobre a previsibilidade do plenário e de alterações nas coalizões. Um partido pode ter votado de forma coesa numa votação, mas contrário à bancada (do governo ou da oposição) da qual fazia parte. A imprevisibilidade devese não à falta de disciplina, mas de uma decisão partidária em votar no sentido oposto ao do conjunto da bancada. Infelizmente, esta análise não pôde ser feita no âmbito deste trabalho.

Tabela 4

Taxa de Previsibilidade das Votações Nominais na Alesc (1999-2006)

\begin{tabular}{lcc}
\hline Legislatura & Votações Previsíveis & Votações Não-Previsíveis \\
\hline $14^{\mathrm{a}}(1999-2002)$ & $87,2 \%(109)$ & $12,8 \%(16)$ \\
$15^{\mathrm{a}}(2003-2006)$ & $86,1 \%(130)$ & $13,9 \%(21)$ \\
Total $(1999-2006)$ & $86,6 \%(239)$ & $13,4 \%(37)$ \\
\hline
\end{tabular}

Fonte: Necip. 


\section{Coalizões partidárias}

A análise do padrão das coalizões partidárias objetiva testar o grau de semelhança existente no posicionamento dos parlamentares de partidos que fazem parte do mesmo bloco ideológico (esquerda-direita) ou parlamentar (situação ou oposição), em cada votação em plenário. No âmbito da Assembléia de Santa Catarina, testaremos a tese formulada por Figueiredo e Limongi (1999) de que o comportamento dos partidos políticos no plenário obedece uma escala ideológica que vai da direita para a esquerda, sendo que os partidos adjacentes teriam grande probabilidade de adotarem a mesma posição no momento da votação, e essa probabilidade diminuiria significativamente de acordo com a distância dos partidos nesse continuum ideológico. Mas, outra hipótese que norteia a presente análise é a de que o posicionamento dos partidos em face da polaridade governo-oposição (que nem sempre segue o posicionamento ideológico) é de grande relevância no Legislativo. Dependendo dos posicionamentos ideológicos que compõem as bancadas governista e oposicionista (em cada legislatura), pode haver maior ou menor grau de superposição dessas duas dimensões (governo/oposição versus direita/esquerda). A análise dos dados permitirá verificar o peso de cada uma delas no comportamento das bancadas. ${ }^{21}$

Nesta análise serão também considerados os partidos em que pelo menos um deputado participou da votação, de forma a incluir as pequenas siglas. É certo que isso implica em inferência mais frágil (comparativamente a um partido com maior número de parlamentares), já que um posiciona- mento idiossincrático do deputado que é o único representante do partido será tomado como indicativo do comportamento da legenda. Assim, talvez devamos ser mais cautelosos em relação às conclusões referentes aos pequenos partidos. De qualquer forma, essa é uma maneira de se obter alguma informação a respeito do comportamento de seus representantes no plenário.

Apesar de não ser muito utilizada no âmbito da Assembléia Legislativa, a indicação da posição partidária por parte do líder reforça a hipótese do padrão ideológico das coalizões entre os partidos. Valem aqui as mesmas ressalvas feitas em relação à análise da disciplina partidária com base nas indicações dos líderes. Os partidos pequenos não foram incluídos na Tabela 5 simplesmente porque, em geral, são formados por apenas um parlamentar. E mesmo os que possuem dois parlamentares ou um pouco mais também não foram incluídos, uma vez que os líderes de pequenas bancadas habitualmente não fazem indicação da posição do partido. Sendo assim, o número limitado de indicações desses partidos poderia generalizar a posição do partido tendo por base apenas algumas poucas votações. Optamos, nesta análise, por considerar apenas os dados de partidos com maior número de indicações. $\mathrm{O}$ PSDB não foi incluído porque houve muito poucos casos em que ocorreu indicação de voto do líder do partido concomitantemente à indicação de líderes de outros partidos.

É possível perceber semelhança entre as indicações na grande maioria dos casos em votações em que há simultaneamente indicação de voto pelos líderes dos dois principais partidos de direita (PP/PPB e PFL). Em menor grau, comportamento

Tabela 5

Percentual (e número) de Casos em que Líderes de Dois Partidos Indicaram Votos de Forma Semelhante (1999-2006)

\begin{tabular}{lcccc}
\hline & PFL & PMDB & PDT & PT \\
\hline PP & $88,2 \%(17)$ & $26,3 \%(19)$ & $38,4 \%(13)$ & $46,1 \%(39)$ \\
PFL & - & $62,5 \%(8)$ & $0 \%(2)$ & $41,1 \%(17)$ \\
PMDB & - & - & $100,0 \% 11)$ & $56 \%(25)$ \\
PDT & - & - & & $66,6 \%(18)$ \\
\hline
\end{tabular}

Fonte: Necip/UFSC. 
parecido ocorre no que se refere às "coalizões" entre os dois principais partidos de esquerda (PT e PDT). Das 17 votações em que tanto o líder do PP (PPB) como o líder do PFL indicaram voto às suas bancadas, a taxa de semelhança foi de $88 \%$. No mesmo período, os líderes do PT e PDT indicaram a mesma posição à sua bancada em 67\% dos 18 casos em que ambos se manifestaram. Inversamente, diante das indicações de voto do líder do PT, os menores percentuais de semelhança têm relação com as indicações de voto dos líderes do PFL (apenas $41,1 \%$ dos casos em que os dois se manifestaram) e do PP/PPB (46\%). No entanto, nem todos os dados revelam que as coalizões seguiram padrões de coerência ideológica estrita, pois há casos em que a semelhança da indicação entre partidos que estão nos extremos do espectro é maior do que quando comparados aos partidos de centro. Para ilustrar essa situação basta observar que a semelhança de voto do PP (PPB) com o PT (partidos de direita e de esquerda, respectivamente) é maior $(46 \%)$ do que o percentual $(26 \%)$ de semelhança entre PP (PPB) e PMDB, um partido de centro. Isso parece indicar que o padrão das coalizões é influenciado também (ou até mais) pela polaridade governo/oposição.

Como na Alesc, diferentemente do que ocorre na Câmara dos Deputados, o posicionamento oficial do partido mediante indicação do líder raramente ocorre, para analisar comparativamente o posicionamento dos partidos sem perder a maioria das votações em plenário, foi necessário então basear-se também no "índice de semelhança", indicador proposto por Figueiredo e Limongi (2006, pp. 270-271) que mede a proporção de votos semelhantes entre dois partidos numa mesma votação. ${ }^{22}$

No que se refere ao PP (PPB), no conjunto das duas legislaturas os maiores índices de semelhança foram estabelecidos com o PFL (76\%) e PTB (62\%), dois partidos à direita do espectro ideológico. Mas, em segundo lugar apareceu o PSB (54\%), o PSDB $(50 \%)$ e o PSOL $(50 \%)$, dois deles partidos situados à esquerda. ${ }^{23}$ Ocorreram ainda muitas diferenças de padrão entre a $14^{\mathrm{a}}$ e a $15^{\mathrm{a}}$ legislaturas em relação às afinidades do $\mathrm{PP}$ (PPB).

$\mathrm{Na} 14^{\text {a }}$, houve forte semelhança entre o PP (PPB) e as posições do PFL, do PSDB, do PTB (e, em menor grau, PL), partidos que então compu- nham a base do governo Amin. Já na legislatura seguinte, com exceção do PFL, as semelhanças mais significativas se deram com partidos de esquerda (PSB, PT e PSOL). O PSB estava formalmente na base de apoio ao governo Luiz Henrique (PMDB), mas os outros dois encontravam-se na oposição, tal qual o PP.

O comportamento do PFL, no que diz respeito às coalizões - com exceção do PSB (em relação ao qual já foi feita uma ressalva) -, seguiu um padrão basicamente ideológico: os maiores índices de semelhança ocorreram com PP (PPB) $(76 \%)$ e PTB $(68 \%)$, partidos de direita; houve depois uma pequena inversão ao que seria esperado se o comportamento seguisse rigorosamente a classificação ideológica dos partidos: o índice de semelhança com o PSDB (de centro) foi um pouco maior do que com o do PL (de direita). Em seguida, o PMDB (de centro), os partidos de centro-esquerda (PDT e PPS) e os partidos de esquerda (PT e PSOL) mantiveram-se distantes do comportamento pefelista em plenário. Mas há uma variação significativa do comportamento do PFL entre as duas legislaturas: os índices de semelhança com partidos de direita declinaram muito, enquanto aumentaram tais índices com partidos de centro e centro-esquerda que faziam (como o PFL) parte da base do governo Luiz Henrique. De qualquer forma, mesmo com o PP na oposição, o PFL manteve com ele seu segundo maior índice de semelhança (o primeiro se deu com o PPS, de centro-esquerda) durante $15^{\text {a }}$ Legislatura. Mas os índices de semelhança entre o PFL e os demais partidos, nos dois primeiros anos da $15^{\mathrm{a}} \mathrm{Le}-$ gislatura variaram muito em relação aos índices encontrados nos dois últimos anos desta Legislatura.

O comportamento do PTB foi um pouco menos consistente no plano ideológico do que o do PFL, mas seguiu basicamente a tendência de maiores índices de semelhança com partidos de direita e centro (se compararmos aos de esquerda). As variações entre as duas legislaturas foram semelhantes às do PFL. O PL apresentou mais semelhanças com partidos de centro (PSDB e PMDB) e um de direita (PTB). Mas especialmente na $15^{\mathrm{a}}$ Legislatura, teve maior semelhança com partidos de centro-esquerda (PDT e PSB) do que com os partidos de direita (PP e PFL). 
Tabela 6

Índice (\%) de Semelhança nas Votações Nominais (Alesc -1999-2006)

\begin{tabular}{|c|c|c|c|c|c|c|c|c|c|c|c|}
\hline Partido & Legislatura & PFL & PTB & PL & PMDB & PSDB & PPS & PDT & PSB & PT & PSOL \\
\hline \multirow[t]{3}{*}{ PP } & $14^{\mathrm{a}}$ & 84 & 88 & 58 & 40 & 68 & 32 & 39 & ND & 25 & ND \\
\hline & $15^{\mathrm{a}}$ & 68 & 41 & 40 & 35 & 37 & 40 & 26 & 54 & 50 & 50 \\
\hline & Total & 76 & 62 & 44 & 38 & 50 & 33 & 35 & 54 & 39 & 50 \\
\hline \multirow[t]{3}{*}{ PFL } & $14^{\mathrm{a}}$ & - & 85 & 62 & 48 & 72 & 39 & 46 & ND & 29 & ND \\
\hline & $15^{\mathrm{a}}$ & - & 54 & 54 & 54 & 55 & 90 & 54 & 58 & 32 & 34 \\
\hline & Total & - & 68 & 56 & 51 & 62 & 46 & 48 & 58 & 30 & 34 \\
\hline \multirow[t]{3}{*}{ РТВ } & $14^{\mathrm{a}}$ & - & - & 66 & 39 & 69 & 33 & 40 & ND & 24 & ND \\
\hline & $15^{\mathrm{a}}$ & - & - & 80 & 81 & 83 & 67 & 81 & 77 & 46 & 56 \\
\hline & Total & - & - & 77 & 63 & 77 & 38 & 51 & 77 & 36 & 56 \\
\hline \multirow[t]{3}{*}{ PL } & $14^{a}$ & - & - & - & 53 & 67 & 52 & 60 & ND & 60 & ND \\
\hline & $15^{\mathrm{a}}$ & - & - & - & 82 & 85 & 56 & 63 & 65 & 51 & 56 \\
\hline & Total & - & - & - & 75 & 82 & 53 & 61 & 65 & 53 & 56 \\
\hline \multirow[t]{3}{*}{ PMDB } & $14^{a}$ & - & - & - & - & 57 & 87 & 87 & ND & 69 & ND \\
\hline & $15^{a}$ & - & - & - & - & 90 & 97 & 76 & 59 & 45 & 26 \\
\hline & Total & - & - & - & - & 77 & 89 & 84 & 59 & 55 & 26 \\
\hline \multirow[t]{3}{*}{ PSDB } & $14^{a}$ & - & - & - & - & - & 56 & 63 & ND & 36 & ND \\
\hline & $15^{\mathrm{a}}$ & - & - & - & - & - & 94 & 76 & 64 & 47 & 31 \\
\hline & Total & - & - & - & - & - & 63 & 67 & 64 & 42 & 31 \\
\hline \multirow[t]{3}{*}{ PPS } & $14^{a}$ & - & - & - & - & - & - & 91 & ND & 72 & ND \\
\hline & $15^{\mathrm{a}}$ & - & - & - & - & - & - & 58 & 58 & 13 & 15 \\
\hline & Total & - & - & - & - & - & - & 87 & 58 & 63 & 15 \\
\hline \multirow[t]{3}{*}{ PDT } & $14^{\mathrm{a}}$ & - & - & - & - & - & - & - & ND & 67 & ND \\
\hline & $15^{\mathrm{a}}$ & - & - & - & - & - & - & - & 67 & 42 & 64 \\
\hline & Total & - & - & - & - & - & - & - & 67 & 60 & 64 \\
\hline \multirow[t]{3}{*}{ PSB } & $14^{\mathrm{a}}$ & - & - & - & - & - & - & - & - & ND & ND \\
\hline & $15^{a}$ & - & - & - & - & - & - & - & - & 56 & 65 \\
\hline & Total & - & - & - & - & - & - & - & - & 56 & 65 \\
\hline \multirow[t]{3}{*}{ PT } & $14^{a}$ & - & - & - & - & - & - & - & - & - & ND \\
\hline & $15^{\mathrm{a}}$ & - & - & - & - & - & - & - & - & - & 88 \\
\hline & Total & - & - & - & - & - & - & - & - & - & 88 \\
\hline
\end{tabular}

Obs.: Na 14ª Legislatura (1999-2002), PSB e PSOL não tinham representante na Alesc.

Fonte: Banco de dados Necip/UFSC, a partir dos Diários da Assembléia Legislativa de Santa Catarina.

Quanto ao PMDB, seus maiores índices de semelhança se deram com partidos de centro-esquerda (PPS e PDT), de centro (PSDB) e com pequenos partidos de direita (PL e PTB). Os menores ocorreram com o PSOL, o PP (PPB) e o PFL. Mas houve variações significativas entre a $14^{\mathrm{a}}$ e a $15^{\mathrm{a}}$ legislaturas: aumento marcante dos índices de semelhança de vários partidos (especialmente o PSDB e os pequenos partidos de direita) com o PMDB, quando este deixou de ser oposição para se tornaro principal partido da base do governo. Os índices declinaram principalmente com PP e PT, principais partidos de oposição ao governo Luiz Henrique. O PSDB, de acordo com seu posicionamento em face dos dois governos, diminuiu drasticamente seu índice de semelhança com o PPB (PP) e aumentou com o PMDB (e os partidos que passaram a fazer parte da base do governo Luiz Henrique). 
O PPS teve maior semelhança com os partidos PMDB, PDT, PSDB e PT. Manteve-se mais distante dos partidos de direita (PP, PTB e PFL), embora seu menor índice de semelhança tenha sido com o PSOL. Mas mudou muito seu comportamento de uma legislatura a outra, aproximando-se dos partidos de direita (especialmente o PFL) e centro e afastando-se do PDT e do PT. Quanto ao PDT, apresentou maior semelhança com os partidos de centroesquerda (PPS, PSB) e centro (PMDB e PSDB), seguindo-se os mais à esquerda (PSOL e PT) e, por último, os de direita (PP, PFL e PTB). O PT teve mais proximidade com os partidos de esquerda (PSOL, PDT e PPS e, em menor grau, PSB), vindo a seguir o PMDB, distanciando-se dos partidos mais à direita e do PSDB. Porém, houve também uma mudança importante entre as duas legislaturas: na $15^{\mathrm{a}}$ o PT esteve mais próximo do PP (embora com um índice não muito elevado, de 50\%) do que dos partidos de centro (PMDB e PSDB) e mesmo alguns de centro-esquerda (PPS e PDT) que faziam parte da base do governo Luiz Henrique. Embora com algumas diferenças, comportamento semelhante apresentou o PSOL na $15^{\mathrm{a}}$ Legislatura.

Numa visão mais panorâmica, percebe-se que durante a $14^{a}$ Legislatura (1999-2002), quando um partido de direita comandou o Executivo (PP), o padrão das coalizões parece ter seguido mais de perto a disposição ideológica dos partidos ao longo de um continuum direita-esquerda, sendo que os parti- dos que apoiavam o governo eram de direita (PFL, PTB, PL) além de um partido de centro (PSDB), e na oposição se encontravam os partidos de esquerda (PT, PDT, PPS) e também o PMDB, de centro. Porém, no início da $15^{\mathrm{a}}$ Legislatura, algumas mudanças começaram a se forjar. Em primeiro lugar, um partido de centro conquistou o Executivo; depois observa-se ao longo da legislatura um padrão em que a base governista recebia apoio - senão formal pelo menos na prática - de partidos tanto do bloco ideológico da direita (PTB, PL e aos poucos também do PFL) como do bloco de esquerda (PPS, PSB e PDT). Ao mesmo tempo, no bloco oposicionista, partidos de diferentes concepções ideológicas, como PP e PT, passaram a votar de maneira bastante semelhante. O posicionamento da maioria dos partidos ante a coalizão governista foi relativamente constante, mas sobretudo o PFL e o PT mudaram seu comportamento com o tempo, como se pode ver na Tabela 7 .

O PFL, que havia apoiado Amin na disputa de 2002, inicia a legislatura com um comportamento em plenário muito mais próximo ao do $\mathrm{PP}$ (índice de semelhança de 83,2\%), distanciando-se dos dois principais partidos da base governista (PMDB e PSDB, índices de semelhança de 30,9\% e 34,8\%, respectivamente). Em 2004, iniciou uma trajetória de aproximação com os partidos governistas, mas ainda se manteve mais aliado com o PP. Somente a partir de 2005 é que o PFL assumiu claramente sua

Tabela 7

Índice de Semelhança nas Coalizões em Plenário, Feitas por PT e PFL na $15^{\text {a }}$ Legislatura, ano a ano (Alesc-2003-2006) (\%)

\begin{tabular}{lcccccccc}
\hline & \multicolumn{2}{c}{2003} & \multicolumn{2}{c}{2004} & \multicolumn{2}{c}{$\mathbf{2 0 0 5}$} & \multicolumn{2}{c}{$\mathbf{2 0 0 6}$} \\
\cline { 2 - 9 } & PFL & PT & PFL & PT & PFL & PT & PFL & PT \\
\hline PP & 83,2 & 34,5 & 72,6 & 62,2 & 41,1 & 63,4 & 48,2 & 61,5 \\
PMDB & 30,9 & 72,2 & 47,5 & 30,0 & 91,8 & 12,1 & 87,7 & 26,9 \\
PSDB & 34,8 & 72,4 & 48,3 & 35,2 & 91,2 & 11,6 & 86,8 & 32,8 \\
PT & 27,5 & - & 48,3 & - & 17,8 & - & 32,3 & -
\end{tabular}

Obs.: Número de votações: 2003: 64; 2004: 41; 2005: 28; 2006: 18. A grande maioria dos “cruzamentos" entre partidos apresentados na tabela envolve a totalidade (ou quase) das votações a cada ano.

Fonte: Necip. 
posição na base parlamentar de apoio a Luiz Henrique. Nos dois últimos anos da legislatura apresentou índices de semelhança em torno de $90 \%$ com PMDB e PSDB, afastando-se bastante do PP (média de $45 \%$ de semelhança).

O PT fez trajetória oposta. Tendo apoiado Luiz Henrique no $2^{\circ}$ turno da eleição de 2002, havia a expectativa de que o partido apoiaria o governo, reforçando uma estratégia de aproximação entre PT e PMDB, já que em âmbito nacional esperavase que o PMDB apoiasse Lula. Em 2003, realmente, o PT não fez uma oposição ferrenha ao governo e, na grande maioria dos casos, votou junto com a base do governo (índices de semelhança de 72\% com PMDB e PSDB). A partir de 2004, porém, o partido passou a fazer em oposição clara a Luiz Henrique, o que se refletiu, em termos de comportamento em plenário, na queda dos índices de semelhança com PMDB (para 30\%) e PSDB (para $35 \%$ ) e na aproximação com o PP (índice de $62,2 \%$, quando em 2003 havia sido de apenas 34,5\%). Nos anos seguintes (especialmente em 2005) afastou ainda mais da base governista, mantendo comportamento mais próximo ao do PP.

Assim, especialmente após a primeira sessão legislativa (2003) da 15 Legislatura, o comportamento dos partidos em plenário, em termos de coalizões, nas votações nominais se afastou do padrão de proximidade ideológica.

\section{Conclusões}

As taxas de disciplina (ou coesão) partidária foram relativamente elevadas para todos os partidos no período entre 1999 e 2006 (média de 92\%), quando se leva em conta apenas os parlamentares presentes em plenário e que não se abstiveram de votar nas votações nominais da Alesc. Quando consideramos, porém, ausências e abstenções, cai bastante a coesão partidária (na média geral, de 92\% para $70 \%$ ). Os dados de que dispomos não permitem afirmar categoricamente que a ausência no plenário seria uma estratégia usada por parlamentares para não terem que votar com o partido (já que pode haver outros motivos que justifiquem as ausências, como viagens, problemas de saúde etc.).
Mas, dada a magnitude desse fato, é bem possível que exista uma estratégia dessa natureza.

O percentual de votações previsíveis (quando o resultado "teoricamente esperado" coincide com o resultado efetivo) foi de $87 \%$ na média do período. Esse percentual é suficiente para questionar a tese de uma alta imprevisibilidade das votações. Indica também que ausências e abstenções acabam por não ter um impacto tão grande nos resultados quanto a queda de coesão média dos partidos poderia sugerir. Resta saber se esta é uma taxa alta ou baixa em face dos padrões internacionais. Além disso, os resultados baseiam-se unicamente na análise quantitativa do total de votações nominais do período em questão, sem distinguir as matérias por sua importância ou grau de conflito. Se as votações mais relevantes realizadas no período estivessem justamente entre os $13 \%$ cujos resultados são "teoricamente" imprevistos, isso significaria que as ausências, as abstenções e a "indisciplina aberta" (voto contra a indicação do líder ou contra a maioria do partido) teriam impacto relevante no processo decisório da Alesc. Não foi possível fazer, porém, no âmbito deste estudo, uma análise separada das propostas que geraram debate mais amplo no âmbito da Assembléia e também da sociedade. Só uma análise desta natureza poderá lançar luz sobre os temas aqui tratados.

Há variações significativas nas taxas de coesão entre os partidos: os partidos mais à direita $(\mathrm{PP} /$ $\mathrm{PPB}$ e PFL) tiveram as menores taxas de uma maneira geral; desconsiderando ausências e abstenções, o PT foi o partido mais coeso, mas quando entram em jogo tais variáveis, o PMDB e o PSDB passam à sua frente. Em relação aos partidos de centro e de direita, levando em conta essas variáveis, há uma tendência de percentuais de disciplina (ou coesão) mais elevados quando os partidos estão na base de apoio ao governo (ou quando têm maior peso no interior desta base), comparativamente a quando estão na oposição (ou quando têm menor importância na composição do governo). Ou seja, participar do governo (e, preferencialmente, com peso na sua formação) parece estimular a coesão partidária em plenário para os partidos situados à direita ou ao centro do espectro ideológico. Quanto aos partidos de esquerda, não foi possível fazer infe- 
inferências sobre o eventual impacto da sua participação no governo sobre sua coesão em plenário.

No que se refere às coalizões em plenário, registramos que na primeira das duas legislaturas estudadas a dimensão governo/oposição tinha forte alinhamento com o posicionamento ideológico dos partidos (governo de direita com apoio de um partido de centro e oposição dos partidos de esquerda e um partido de centro). Já na segunda legislatura, houve um afastamento desse padrão (governo envolvendo partidos que vão da direita à centro-esquerda; oposição feita por partidos de direita e de esquerda). As tendências encontradas em nossa aná- lise estão em acordo com os dados apresentados por Santos (2006a), Figueiredo e Limongi (2007) no âmbito da Câmara dos Deputados. Apesar de as duas dimensões terem algum peso no comportamento parlamentar, no conjunto dos dados analisados a dimensão governo/oposição revelou ser mais significativa na formação de coalizões em plenário do que o posicionamento dos partidos na escala ideológica. Ou seja, a semelhança de voto em plenário entre deputados de dois partidos diferentes depende mais de eles pertencerem à mesma bancada (do governo ou da oposição) do que de pertencerem a partidos do mesmo campo ideológico.

Tabela Anexa 1

Variação do Número de Deputados por Partido no Decorrer das $14^{a}$ e $15^{a}$ Legislaturas (1999-2006)

\begin{tabular}{lcccccc}
\hline \multirow{2}{*}{ Partido } & \multicolumn{2}{c}{$\mathbf{1 4}^{\mathbf{a}}$ Legislatura (1999-2002) } & \multicolumn{2}{c}{$\mathbf{1 5}^{\mathbf{a}}$ Legislatura (2003-2006) } \\
\cline { 2 - 6 } & Eleitos & Máximo & Mínimo & Eleitos & Máximo & Mínimo \\
\hline PP (PPB) & 10 & 12 & 10 & 10 & 10 & 6 \\
PFL & 9 & 9 & 7 & 8 & 8 & 5 \\
PTB & 1 & 2 & 1 & 2 & 2 & 1 \\
PL & 0 & 1 & 0 & 1 & 1 & 1 \\
PMDB & 10 & 11 & 10 & 7 & 9 & 7 \\
PSDB & 3 & 3 & 1 & 3 & 6 & 4 \\
PSB & 0 & 0 & 0 & 0 & 1 & 0 \\
PPS & 0 & 1 & 1 & 0 & 1 & 0 \\
PDT & 2 & 2 & 1 & 0 & 1 & 0 \\
PT & 5 & 5 & 5 & 9 & 9 & 8 \\
PSOL & 0 & 0 & 0 & 0 & 1 & 0 \\
\hline
\end{tabular}

Fonte: TRE/SC (eleitos); Banco de dados do Necip (número máximo e mínimo de deputados nas legislaturas).

\section{Notas}

1 Entre as prerrogativas do Executivo federal no processo legislativo estão: a capacidade de editar Medidas Provisórias, o pedido de urgência para suas matérias e as vantagens estratégicas na elaboração e execução do Orçamento.

2 O estudo mostra que $89 \%$ dos resultados das votações nominais podem ser previstos corretamente quando se sabe como votam os líderes e qual o tamanho da bancada de cada partido (Figueiredo e Limongi, 1999, p. 12).

3 Uma das razões para esta conclusão, tão diferente dos achados de Figueiredo e Limongi, é de ordem metodológica, principalmente quanto aos critérios para definir uma votação como consensual (o que será retomado adiante) (Mainwaring, 2001, p. 182).

4 Nicolau (2000) já havia chamado a atenção deste problema das ausências em plenário sobre o grau de disciplina partidária.

5 Figueiredo e Limongi (1999, 2006, 2007); Novaes (1994); Meneguello (1998); Nicolau (2000); Pereira e Mueller (2003); Santos (2001; 2006a e b); Amorim Neto (2000 e 2006); Amorim Neto e Santos (2001), Pereira e Mueller (2003); Leoni (2002); Rennó (2006), Melo (2007), entre outros.

6 Em outras palavras, é consensual a votação em que não haja pelo menos $10 \%$ dos deputados presentes 
votando contra a maioria do plenário. Mainwaring utiliza como "ponte de corte" o percentual de 25\% de oposição à maioria. Para uma defesa do critério aqui adotado, ver Figueiredo e Limongi (1999, p. 109, n. 76). Tanto Figueiredo e Limongi (1999, p. 95), como Santos (2006, p. 233), além dos 90\% como ponto de corte, incluem outro critério adicional para definir uma votação como consensual: o encaminhamento de voto de forma semelhante por parte das lideranças dos grandes partidos. Em nosso estudo, como a proporção de casos em que os líderes dão indicação de voto às suas bancadas é muito pequena, utilizar este critério implicaria em deixar de fora a grande maioria das votações nominais. Por isso, utilizamos apenas o percentual de pelo menos $10 \%$ de oposição à maioria em plenário.

7 A literatura (Amorim Neto, 2000, 2006; Santos, 2006a; Figueiredo e Limongi, 2007) tem tomado como indicador de participação na formação de governo, em âmbito nacional, o fato de um partido ter ou não cadeira(s) no Ministério. É partir daí que se analisa o comportamento de um partido na Câmara Federal. Em âmbito estadual, o indicador similar deveria ser o fato de um partido ocupar uma Secretaria de Estado. Em nosso estudo, porém, verificamos que ocorreram mudanças no posicionamento de partidos no âmbito da Asssembléia Legislativa (da oposição para a base do governo ou vice-versa) sem que houvesse mudanças na participação (ou não) no secretariado estadual. Outras formas de "participação", como será visto, podem atrair um partido para a base de governo.

8 A Tabela Anexa 1 apresenta o número de deputados eleitos e o número mínimo e máximo que cada partido teve ao longo de cada legislatura nas votações nominais, de forma a dar uma idéia da variação de sua bancada. $\mathrm{Na}$ análise da disciplina e das coalizões, no entanto, os parlamentares foram considerados como "pertencentes" ao partido a que estavam filiados no momento da votação.

9 Ao final da $14^{a}$ Legislatura alguns partidos da base (PSDB e PL) aproximaram-se de outros da oposição, tendo em vista formarem coligação para o pleito de 2002, mas isso não implicou num posicionamento de oposição nas votações na Alesc.

10 Segundo declaração do então líder do PPB, os dois únicos casos em que houve migração de deputados da base do governo para a oposição decorreram de eles terem seus interesses pessoais contrariados pelo governo.

11 Segundo o deputado Joares Ponticelli, que ocupou a vice-liderança do governo Amin entre 1999 e 2000 e depois a liderança (2001/2002), "houve uma habilidade muito grande por parte do governador Luiz Henrique logo no início da $15^{a}$ Legislatura, de aproximar o governo de alguns deputados do PFL e esses começaram a envolver os demais, a ponto de que a resistência, ao final do primeiro ano, estava restrita aos deputados Antonio Ceron e João Paulo Kleinubing. Depois, com a saída do deputado João Paulo em 2004 para disputar a eleição, essa resistência foi desaparecendo e ao final de 2004 e início de 2005 já havia uma integração total do PFL ao governo. Não fizeram uma opção pelo espaço formal, mas o governo passou a dispensar uma atenção muito grande ao PFL. E acabou levando o PFL a apoiar a candidatura da reeleição em 2006" (Entrevista concedida a Eduardo Perondi, em novembro de 2007). Conversas informais com um assessor parlamentar indicam que o acerto para eleger o deputado pefelista Júlio Garcia à presidência da Alesc (2005/2006), bem como os arranjos nas Secretarias Regionais e o atendimento, por parte destas, a pleitos de prefeitos do PFL, teriam sido importantes para atrair o apoio do partido ao governo.

12 Seguindo boa parte da literatura, no presente estudo os partidos que tiveram representação na Alesc no período analisado foram classificados num bloco de direita (PP/PPB, PFL, PTB e PL), um ao centro do espectro (PMDB e PSDB) e outro à esquerda (PPS, PDT, PSB, PT e PSOL).

13 Os percentuais foram calculados sobre o número de deputados de cada partido presentes no momento da votação (incluindo aí os que se abstiveram de votar). Como será visto mais adiante, se calcularmos os percentuais de disciplina sobre o total de deputados de cada partido (incluindo os que se ausentaram), há um aumento significativo da indisciplina.

14 Isso nos foi informado pelo então assessor da bancada e Secretário do Diretório Estadual do PMDB, Adélcio Machado, que tinha muito conhecimento do relacionamento entre as bancadas dos diferentes partidos e o líder do governo na Alesc.

15 Assim, se 20\% votaram "sim" e 80\% votaram "não", será considerado um percentual de coesão partidária de $80 \%$ nesta votação. Teoricamente pode ocorrer de a maioria votar contra a indicação do líder: assim, teríamos uma alta coesão, mas isso representaria uma indisciplina contra o líder. Os dados da Tabela 1, porém, indicam que este tipo de conflito (entre líder e bancada) é pouco freqüente: dentro do conjunto de votações em que há indicação de voto por parte do líder, a disciplina média dos cinco maiores par- 
tidos, nas duas legislaturas, é de 92\%. Assim, o número de casos em que há uma alta coesão, mas indisciplina (voto da maioria em oposição à indicação do líder) deve ser muito pequeno (talvez nulo), em nosso universo de pesquisa. Por outro lado, na ausência de indicação de voto pelo líder, formalmente o voto da maioria não representa indisciplina; é possível, porém, casos em que o líder, sabendo que o voto da maioria será contra sua indicação, prefere não se desgastar, não indicando a direção de voto. Não é possível saber os casos em que isso ocorre, mas não temos por que pressupor que haja muitos casos. As entrevistas com líder do governo Amin e com importante assessor do PMDB durante todo o governo Luiz Henrique apontam que não houve conflitos relevantes com a base partidária nas duas legislaturas. Dessa forma, será considerado que, embora o percentual de coesão não seja um indicador preciso, pode ser um indicador aproximado da disciplina partidária.

16 Conforme Figueiredo e Limongi (1999, p. 82), “o índice de Rice varia entre zero e 100 e é computado subtraindo-se a proporção de votos minoritários dos majoritários. Quando 50\% do partido votam 'sim' e $50 \%$ votam 'não', esse índice é igual a zero. Quando há total unidade, o índice é igual a 100. Será igual a 70 se $85 \%$ dos membros estiverem de um lado e $15 \%$ do outro". Em nosso caso, neste último exemplo, houve uma taxa de coesão de $85 \%$, expressão cuja compreensão nos parece mais intuitiva do que um índice de Rice de 70.

17 Nos casos em que havia - no Diário da Alesc, em que são transcritos os debates que precedem às votaçõesindicação do líder para que o partido obstruísse, se retirando do plenário, a taxa de coesão foi calculada com base no percentual dos deputados que seguiram esta indicação. Há alguns outros casos em que parece ter havido uma estratégia de obstrução, já que todos os deputados do partido estavam ausentes. Como, porém, não havia uma indicação pública desta estratégia por parte do líder, eles não foram considerados no cálculo do indicador de coesão.

18 Foram consideradas, para cada partido, apenas as votações em que pelo menos dois deputados do partido estavam presentes no plenário e não se abstiveram de votar. Isso exclui da análise todos os partidos cuja bancada era formada por apenas um parlamentar (caso de PL, PPS, PSB e PSOL). Quanto ao PDT, como em todo período teve apenas duas votações que atendessem estes critérios, foi retirado também da análise.
19 A título de exemplo, no caso de um partido com dez deputados, dos quais três se ausentaram numa votação, cinco votaram "sim”, um votou "não" e um se absteve, o grau de coesão nesta votação, se desconsiderarmos as ausências e as abstenções, será de $83,3 \%$ (já que dos seis que estavam presentes e não se abstiveram, cinco votaram da mesma forma). Considerando as ausências e as abstenções, o grau de coesão será calculado sobre o total de deputados do partido na Alesc e não sobre o total de presentes na votação. Neste caso, o grau de disciplina seria de $50 \%$, já que cinco dos dez deputados (em exercício) do partido votaram da mesma forma. Foram consideradas, para cada partido, apenas as votações em que havia pelo menos dois deputados filiados ao partido no momento da votação.

20 Certamente utilizar como "posição do partido" o voto que efetivamente foi dado pela maioria dos deputados do partido, numa determinada votação, não é tão adequado quanto utilizar a indicação de voto do líder para depois calcular quantos votos deveria ter cada posição -"sim" ou "não" -, supondo a presença e a disciplina total dos deputados Mas como o percentual de casos em que os líderes indicavam voto era pequeno, julgamos que o uso desse outro indicador permitiria ao menos um teste do grau de previsibilidade do plenário de forma a verificar se o impacto das ausências e das abstenções - que, no que concerne às taxas de coesão, parece elevado quando comparados os dados das Tabelas 2 e 3 - resultaria numa baixa previsibilidade das votações.

21 Quanto à classificação dos partidos segundo seu posicionamento ideológico, ver nota 10 ; quanto à polaridade governo-oposição, ver Quadro 1.

22 Agradecemos a Fernando Limongi pelas informações a respeito da fórmula de cálculo (adaptada para porcentagem) utilizada por ele: Índice de Semelhança = $100-1 \% \mathrm{Si}-\% \mathrm{Sj}_{1}$, , onde $\% \mathrm{Si}$ é o percentual de votos "sim" do Partido i (calculado assim: $\% \mathrm{Si}=100 *[\mathrm{Si}$ / $(\mathrm{Si}+\mathrm{Ni})$ ], sendo $\mathrm{Si}$ e Ni os números de votos "sim" e "não" do partido i numa determinada votação) e Sjé o percentual de votos "sim" do Partido $j$ (calculado de forma semelhante). A subtração das duas percentagens é feita em módulo. Por exemplo: PMDB tem 100 deputados, dos quais 80 votaram "sim" e 20 votaram "não"; PFL tem 50 deputados, dos quais 35 votaram "sim" ( $70 \%$, portanto) e 15 votaram "não" $(30 \%)$. Índice de semelhança (PMDB $/ \mathrm{PFL})=100$ $\{|100 *[80 /(80+20)]-100 *[35 /(35+15)]|\}=100$ - $|80-70|=90$, isto é, $90 \%$. Se fosse calculado com base nos percentuais de "Não" (sobre total de "sim" 
+ “não”), o resultado seria o mesmo. Vale notar que o cálculo toma como denominadores as somas apenas dos votos "sim" e "não"; abstenções e ausências não são consideradas. Vamos utilizar aqui esta mesma fórmula..

23 Deve-se fazer a ressalva de que o único parlamentar que o PSB teve (na 15 Legislatura) foi fruto da migração de um deputado de perfil conservador que havia sido eleito pelo PTB.

\section{BIBLIOGRAFIA}

ABRUCIO, Fernando. (1998), Os barões da federação. São Paulo, Hucitec.

AMES, Barry. (2003), Os entraves da democracia no Brasil. Rio de Janeiro, Editora da FGV.

AMORIM NETO, Octavio. (2000), "Gabinetes presidenciais, ciclos eleitorais e disciplina legislativa no Brasil". Dados, 43 (3): 479-520.

- (2006), Presidencialismo e governabilidade nas Américas. Rio de Janeiro, Editora da FGV/ Konrad-Adenauer Stiftung.

AMORIM NETO, Octavio \& SANTOS, Fabiano. (2001), "A conexão presidencial: facções pró e antigoverno e disciplina partidária no Brasil". Dados, 44 (2): 291-322.

ANDRADE, Regis C. (org.). (1998), Processo de governo no município e no estado: uma análise a partir de São Paulo. São Paulo, Edusp.

CARVALHO, Nelson Rojas. (2003), E no início eram as bases: geografia do voto e comportamento legislativo no Brasil. Rio de Janeiro, Revan.

DAHL, Robert. (1999), Poliarquia: participação e oposição. São Paulo, Edusp.

FIGUEIREDO, Argelina \& LIMONGI, Fernando. (1995), "Partidos políticos na Câmara dos Deputados: 1989-1994”. Dados, 38 (3): 497-524. - (1999), Executivo e Legislativo na nova ordem constitucional. Rio de Janeiro, Editora da FGV. . (2006). "Poder de agenda na democracia brasileira: desempenho do governo no presidencialismo multipartidário”, in Gláucio Soares e Lucio Rennó, Reforma politica: lições da bistória recente, Rio de Janeiro, Editora da FGV. . (2007), "Instituições políticas e governabilidade: desempenho do governo e apoio legislativo na democracia brasileira", in Carlos R. Melo e Manuel A. Sáez, A democracia brasileira: balanço e perspectivas para o século 21, Belo Horizonte, Editora da UFMG.

LEONI, Eduardo. (2002), "Ideologia, democracia e comportamento parlamentar: a Câmara dos deputados (1991-98)". Dados, 45 (3): 361-386.

LIMONGI, Fernando. (2006), "Presidencialismo e governo de coalizão", in Leonardo Avritzer e Fátima Anastasia (orgs.), Reforma politica no Brasil, Belo Horizonte, Editora da UFMG/PNUD.

MAINWARING, Scott, P. (2001). Sistemas partidários em novas democracias: o caso do Brasil. Porto Alegre/Rio de Janeiro, Mercado Aberto/Editora da FGV.

MELO, Carlos R. (2007), "Nem tanto ao mar, nem tanto à terra: elementos para uma análise do sistema partidário brasileiro", in Carlos R. Melo e Manuel A. Sáez (orgs.), A democracia brasileira: balanço e perspectivas para o século 21, Belo Horizonte, Editora da UFMG.

MENEGUELLO, Rachel. (1998), Partidos e governos no Brasil contemporâneo (1985-1997). São Paulo, Paz e Terra.

MONTENEGRO, Nelson. (2006), "A produção de leis na Assembléia Legislativa de Santa Catarina (1990-2000)", in Yan Carreirão e Julian Borba, Os partidos na politica catarinense, Florianópolis, Insular.

NICOLAU, Jairo. (2000), "Disciplina partidária e base parlamentar na Câmara dos Deputados no primeiro governo de Fernando Henrique Cardoso (1995-1998)". Dados, 43 (4): 709-734.

NOVAES, Carlos Alberto Marques. (1994), "Dinâmica institucional e representação". Estudos Cebrap, 38: 99-147.

PEREIRA, Carlos e MUELLER, Bernardo. (2003), "Partidos fracos na arena eleitoral e partidos fortes na arena legislativa: a conexão eleitoral no Brasil", Dados, 46 (4): 735-770.

RENNÓ, Lucio. (2006), "Críticas ao presidencialismo de coalizão", in Leonardo Avritzer e Fátima Anastasia (orgs.), Reforma política no Brasil, Belo Horizonte, Editora da UFMG/PNUD.

SANTOS, Fabiano (org.). (2001), O poder Legislativo nos estados: diversidade e convergência. Rio de Janeiro, Editora da FGV. 
. (2006a), "Em defesa do presidencialismo de coalizão", in Gláucio Soares e Lucio Rennó, Reforma política: lições da história recente, Rio de Janeiro, Editora da FGV.

- (2006b), "Governos de coalizão no sistema presidencial: o caso do Brasil sob a égide da Constituição de 1998", in Leonardo Avritzer e Fátima Anastasia (orgs.), Reforma política no Brasil, Belo Horizonte, Editora da UFMG/ PNUD.

SANTOS, F. \& VILAROUCA, M. (2004), "Relatório do primeiro ano do governo Lula". Disponível no site http://necon.iuperj.br/arquivos/ home/relatorio_primeiro_ano_lula.pdf.pdf.

TOMIO, Fabrício R. L. (2006), "Medidas provisórias, iniciativas e decisões legislativas no processo decisório estadual catarinense, in Yan Carreirão e Julian Borba, Ospartidos na política catarinense, Florianópolis, Insular. 


\section{DISCIPLINA E COALIZÕES PARTIDÁRIAS NA ASSEMBLÉIA LEGISLATIVA DE SANTA CATARINA (1999-2006)}

Yan de Souza Carreirão e Eduardo Perondi

Palavras-chave: Partidos políticos; Disciplina partidária; Coalizões parlamentares.

Este artigo analisa a disciplina partidária e as coalizões no plenário da Assembléia Legislativa de Santa Catarina, no período entre 1999 e 2006. Mostra que as taxas de disciplina, embora variem entre os principais partidos, são relativamente elevadas em seu conjunto, levando a uma significativa previsibilidade dos resultados das votações. Quanto às coalizões, a dimensão governo/oposição revelou ser mais significativa na formação de coalizões em plenário do que o posicionamento dos partidos na escala ideológica (esquerda/direita).

\section{DISCIPLINE AND PARTY \\ COALITIONS AT SANTA CATARINA'S HOUSE OF REPRESENTATIVES (1999-2006)}

\section{Yan de Souza Carreirão and Eduardo Perondi}

Keywords: Political parties; Party discipline; Parliamentary coalitions.

This article analyses party discipline and parliamentary coalitions at Santa Catarina's House of Representatives between 1999 and 2006. It shows that discipline ratios, though changing amidst the main parties, have been relatively high as a whole, causing some significant predictability in voting outcome. As for coalitions, the government/opposition dimension has shown to be more significant in parliamentary groupings than in the positioning of parties along the so-called left/right ideological scale.
DISCIPLINE ET COALITIONS PARTIDAIRES À L'ASSEMBLÉE LÉGISLATIVE DE SANTA CATARINA (1999-2006)

Yan de Souza Carreirão et Eduardo Perondi

Mots-clés: Partis politiques; Discipline partidaire; Coalitions parlementaires.

Cet article analyse la discipline partidaire et les coalitions dans les sessions plénières de l'Assemblée Législative de Santa Catarina, dans la période comprise entre 1999 et 2006. Il démontre que les taux de discipline, quoique variant entre les principaux partis, sont, dans leur ensemble, relativement élevés, menant à une prévisibilité significative des résultats des votations. Quant aux coalitions, la dimension gouvernement/opposition s'est révélée être plus significative dans le formation de coalitions en session plénière, que la position des partis dans l'échelle idéologique (gauche/droite). 